\title{
25 Research Square \\ Effects of forest cover pattern on water quality of low-order streams in an agricultural landscape in the Pirapora river basin, Brazil
}

Kaline de Mello

USP: Universidade de Sao Paulo

Roberta Averna Valente

UFSCar: Universidade Federal de Sao Carlos

Marina Pannunzio Ribeiro ( $\square$ marinapr@estudante.ufscar.br )

UFSCar: Universidade Federal de Sao Carlos https://orcid.org/0000-0002-9343-331X

Timothy Randhir

University of Massachusetts Amherst

\section{Research Article}

Keywords: stream water quality, watershed management, forest fragmentation, land use, riparian zone, Atlantic Forest

Posted Date: July 2nd, 2021

DOl: https://doi.org/10.21203/rs.3.rs-422824/v1

License: (9) This work is licensed under a Creative Commons Attribution 4.0 International License. Read Full License

Version of Record: A version of this preprint was published at Environmental Monitoring and Assessment on February 14th, 2022. See the published version at https://doi.org/10.1007/s10661-022-09854-4. 


\section{Abstract}

Low-order streams are important regions for river formation and are highly vulnerable to changes in terrestrial systems. Thus, the land-use/land-cover plays an important role in the maintenance of water quality. However, only its composition may not explain the spatial variation in water quality, because it does not consider landscape configurations. In this context, the study aimed to evaluate the forest cover pattern effects on water quality on low-order streams, which integrated an agricultural landscape. Applying a paired watershed method, we selected watersheds classified according to their morphometry and average slope to discard other physical factors that could influence the water quality. Land-use/landcover pattern was analyzed for composition and forest cover configuration using landscape metrics, including the riparian zone composition. Water quality variables were obtained every two weeks during the hydrological year. This way, watersheds had similar morphometry, slope, and land-use/land-cover composition but differed in landscape configuration. Watershed with more aggregated forest cover had a better water quality than the other one. The results show that forest cover contributes to water quality maintenance, while forest fragmentation influences the water quality negatively, especially in sediment retention. Agricultural practices are sources of sediment and nutrients to the river, especially in steep relief. Thus, in addition to land-use/land-cover composition, landscape pattern must be considered in management of low-order streams in tropical agricultural watersheds.

\section{Declarations}

- Ethics approval and consent to participate: Not applicable

- Consent for publication: Not applicable

- Availability of data and materials: All data generated or analysed during this study are included in this published article

- Competing interests: The authors declare that they have no competing interests

- Funding: This study was supported by the São Paulo Research Foundation (FAPESP, process number 2018/21612-8).

- Authors' contributions: Conceptualization [Kaline de Mello, Roberta Averna Valente, Timothy Randhir], Methodology: [Kaline de Mello, Roberta Averna Valente], Formal analysis and investigation: [Kaline de Mello], Writing - original draft preparation: [Kaline de Mello, Marina Pannunzio Ribeiro]; Writing - review and editing: [Roberta Averna Valente, Timothy Randhir], Funding acquisition: [Kaline de Mello, Roberta Averna Valente], Resources: [Kaline de Mello], Supervision: [Roberta Averna Valente]

- Acknowledgements: We thank the University of São Paulo and the Federal University of São Carlos for the structural support; Dr. Adriana Cristina Poli Miwa (University of São Paulo) and Monica Almeida (Federal University of São Carlos) for helping in the samples processing. We also thanks FAPESP for the research funding. 


\section{Introduction}

Conversion of natural landscapes into agricultural and urban areas to support the increasing human demand of resources is one of the main causes of water quality degradation (Goldstein et al. 2012; Mello et al. 2020). Natural vegetation is often related to good water quality while urban and agricultural lands contribute to the increase of nutrients and sediments in freshwater ecosystems worldwide (Huang et al. 2016; Mello et al. 2018b; Shehab et al. 2021). However, considering only land-use/land-cover composition may not explain the spatial variation in water quality, because it does not include landscape configurations such as patch size, shape, density, or connectivity, which can influence water quality parameters (Ding et al. 2016; Shi et al. 2017; Wu et al. 2021). Landscape pattern can be especially important in low-order streams that are highly influenced by terrestrial flows and are located commonly in the steepest area of the river basin (Campos Pinto et al. 2016; Taniwaki et al. 2017; Mello et al. 2018b). Understanding the relationships between land use patterns and water quality in low-order streams is necessary for effective landscape planning to protect downstream water quality (Ding et al. 2016; Bailão et al. 2020).

Low-order streams ( $1^{\text {st }}$ to $3^{\text {rd }}$-order) dominate a riverine landscape and maintain the function, health, and biodiversity of the entire river networks (Vannote et al. 1980). According to Vannote et al. (1980), they are strongly influenced by terrestrial inputs, which makes them fragile ecosystems that can suffer dramatic impact from land-use changes such as deforestation and fragmentation (Freeman et al. 2007). Thus, anthropogenic activities and degradation of native vegetation in low-order streams can increase nutrients and sediments loading into streams, thereby impacting distant downstream ecosystems (Gomi et al. 2002; Castillo et al. 2012; Ding et al. 2016; Song et al. 2020). These relationships can be enhanced in tropical watersheds, where headwater streams are highly dynamic in intense hydrological cycles and constant disturbances resulting from their topography that induces fast-flow regimes and substrate instability (Taniwaki et al. 2019). Besides land use impacts, climate change is also a great anthropogenic pressure on small tropical streams, which highlights the importance of studies in these fragile ecosystems (Taniwaki et al. 2017).

Natural vegetation has an important role in biogeochemical cycles in tropical agricultural watersheds, and studies show that these flows are stronger in low-order streams, providing protection against erosive processes, sedimentation in water bodies, pollutants retention, excessive leaching of nutrients, and increased water temperature (Schilling and Jacobson 2014; Tanaka et al. 2016; Taniwaki et al. 2017; Mello et al. 2018a). Forest conservation and restoration of watersheds have been recommended as the best solution for keeping or improving water quality for public water supply (Bu et al. 2014; Vettorazzi and Valente 2016; Mello and Randhir 2018; Bakure et al. 2020).

However, early studies have shown that in addition to forest net loss, forest fragmentation influences water quality degradation (Ding et al. 2016; Clément et al. 2017; Shi et al. 2017). According to Shi et al. (2017), landscape composition metrics are only simple predictors, while configuration metrics can be more sensitive predictors of water quality than composition. 
The development of the landscape ecology and Geographic Information System (GIS) allows the inclusion of landscape metrics to understand these relations. Ding et al. (2016) found that patch density, largest patch index, and aggregation index were important predictors for water quality variables. Clément et al. (2017) showed that shape and forest patches location have an impact on water quality. On the other hand, Xie et al. (2018) found that landscape composition seems to be the dominant contributor to water quality variation, compared to habitat fragmentation. In addition, impacts on water bodies are also related to hydrological and physical characteristics of the watershed, and numerous other factors ranging from local to regional scales (Amuchástegui et al. 2016; Álvarez-Cabria et al. 2016; Shi et al. 2017).

Therefore, studies are needed to evaluate the effects of landscape pattern and forest fragmentation on water quality, especially in agricultural, low-order streams, to evaluate the importance of composition and configuration metrics in water quality. This is important to support conservation and management efforts of these fragile ecosystems, as well as the resulting improvement in water quality of downstream ecosystems.

In this context, the main objective of this study is to assess the effects of forest cover pattern on water quality of the low-order streams in an agricultural landscape, which form the main tributaries of a public water supply in Brazil. Thus, a paired watershed method was used in this study. The specific objectives are: (1) to evaluate the relationship between landscape metrics and water quality; (2) to verify if forest configuration influences water quality at small watershed scale; and (3) to evaluate the effect of forest fragmentation on stream water quality.

\section{Materials And Methods}

\section{Study area}

We studied the main tributaries of the Pirapora river, regional named as Gurgel (W1) and Vieirinhas (W2). Pirapora river is one of the main rivers of the Tiete river basin, located in the São Paulo State, southeastern Brazil (Fig 1). They supply three cities and towns, providing water for domestic, agricultural, and other purposes (Silva et al. 2017).

The watershed was originally covered by Atlantic Forest, where Dense Ombrophilous Forest is the predominant forest type. The forest patches remaining are within a complex matrix composed by agriculture (mostly in small scale with annual crops), pasture, planted forest (Eucalyptus sp. and Pinus sp.), and urban areas. Agriculture is the backbone of the economy, especially the production of grains, fruits, and vegetables (Silva et al. 2017). Thus, the population is predominantly rural in the region (IBGE 2020). Another characteristic of the study area is the proximity to two protected areas - Itupararanga Environmental Protection Area and Jurupará State Park due to its great forest cover, unique in the São Paulo State (Silva et al. 2017). 
The predominant soil types in the Pirapora river watershed are red or yellow tropical soils, mainly Latosols and Argisols (Rossi 2017). The local altitude varies from $870 \mathrm{~m}$ to $1,200 \mathrm{~m}$, with a relief characterized by hills with medium to high slopes, with some mountainous areas (Carneiro et al. 1981; EMBRAPA 1999) .

The region is under the influence of Cwa-type climate (humid temperate with dry winters). The average daily temperature in the hottest months is $22.0^{\circ} \mathrm{C}$ and in the colder months is $15.7^{\circ} \mathrm{C}$ (CEPAGRI 2020). Annual precipitation is between $1354.7 \mathrm{~mm}$ and $1807.7 \mathrm{~mm}$ (CEPAGRI 2020), and the rain mostly falls from October to March.

A paired watershed method has been used to verify significant differences between watersheds regarding only the land-use/land-cover pattern. According to Brown et al. (2005), the paired watershed study uses two watersheds with similar characteristics in terms of slope, aspect, soils, area, climate, and vegetation, located adjacent or near to each other.

Thus, we have selected two similar adjacent watersheds (according to the soil, climate, size, shape, slope, and land-use/land-cover composition) based on a previous study (Mello et al. 2018b). The watersheds have common physical characteristics and land-use/land-cover composition, although having different forest configurations (Fig 1).

\section{Watersheds physical characterization}

Map processing and spatial analysis were performed using the Geographical Information System (GIS) with ArcGIS 10.2 (ESRI). Considering that some characteristics of the watersheds may influence water quality, and the objective of the study was to evaluate only the effects of land-use/land-cover pattern, we characterized the watersheds according to morphometry and slope to identify the physical factor that could influence the results of the analysis (Amuchástegui et al. 2016).

River network and a 5 m-resolution Digital Elevation Model (DEM) for each watershed derived from official topographic information (IGC, 1:10,000 scale) were used to extract physical information of the watersheds.

\section{Morphometry}

Watersheds were classified according to their shape, using the following metrics: compactness coefficient (Kc), circularity index (Ic), and shape factor (Kf) (Villela and Mattos 1975). Kc is a relation between the perimeter of the watershed and the circumference of a circle with the area of the watershed (Villela and Mattos 1975). This coefficient refers to a dimensionless value that varies with the shape of 
the watershed, regardless of its size. The more irregular its shape, the greater the $\mathrm{Kc}$, which is determined by Equation (1):

$$
K_{c}=0.28 \times\left(\frac{P}{\sqrt{A}}\right)
$$

Where, $\mathrm{Kc}$ is the compactness coefficient; $\mathrm{P}$ is the perimeter $(\mathrm{m})$; and $\mathrm{A}$ is the drainage area $\left(\mathrm{m}^{2}\right)$.

The Ic increases as the watershed approaches the circular shape and decreases as the shape becomes elongated, simultaneously to the Kc (Cardoso et al. 2006). To obtain Ic, Equation (2) was used:

$$
I_{c}=\left(\frac{(12.57 \times A)}{P^{2}}\right)
$$

where Ic is the circularity index; $A$ is the drainage area $\left(\mathrm{m}^{2}\right)$; and $\mathrm{P}$ is the perimeter $(\mathrm{m})$.

The shape factor $(\mathrm{Kf})$ associates the shape of the watershed with a rectangle, corresponding to the ratio between the average width and the length of the watershed (Cardoso et al. 2006) (Equation 3).

$$
K f=\frac{A}{L^{2}}
$$

where $\mathrm{Kf}$ is the shape factor; $\mathrm{A}$ is the drainage area $\left(\mathrm{m}^{2}\right)$; and $\mathrm{L}$ is the length of the watershed $(\mathrm{m})$.

Watersheds were classified according to their shape (based on Ic and $\mathrm{Kc}$ indexes) as proposed by Villela and Matos (1975): round ( $\mathrm{Ic}=1.00$ to $0.80 ; \mathrm{Kc}=1.00-1.24)$; oval ( $\mathrm{lc}=0.8$ to $0.61, \mathrm{Kc}=1.25$ to 1.50 ); oblong ( $\mathrm{Ic}=0.60$ to $0.40, \mathrm{Kc}=1.50-1.70)$; and long ( $\mathrm{Ic}<0.40 ; \mathrm{Kc}>1.70)$. According to the authors, these formats allow the respective environmental interpretations, regarding the flood tendency of the watershed: high; medium and low. In this way, the shape similarity among watersheds was evaluated.

\section{Slope}

We used the DEM to obtain a slope map in percentage, that supported to calculate average slope of watersheds. After, the slopes were classified according to EMBRAPA (1999) to characterize the relief: 0$3 \%$ = flat relief; $3-8 \%$ = soft-wavy relief; $8-20 \%$ = wavy relief; $20-45 \%$ = highly wavy relief; $45-75 \%=$ mountainous relief; $>75 \%=$ highly mountainous. 


\section{Landscape composition and configuration}

We calculated landscape metrics to evaluate the landscape composition and configuration, based on the land-use/land-cover map, which was created through on-screen digitizing of SPOT images $(2.5 \mathrm{~m}$ spatial resolution; panchromatic band, year: 2010 - Source: SMA-CPLA) with a 1:8,000 scale.

Based on the (IBGE (2013) technical manual of land use, the land-use/land-cover types were defined as water body, wetland, native forest, forestry, pasture, agriculture (annual crops), and urban area (residential and commercial areas).

We calculated the traditional landscape metrics (McGarigal 2015), named percentage of landscape of each land-use/land-cover type (PLand);

- NP - number of forest patches;

- PD - forest patch density, number of patches in 100 ha of the landscape;

- LPI - largest patch index, obtained by the percentage of the landscape covered by the largest forest patch;

- CV - coefficient of variation of the patch size, obtained by dividing the standard deviation of the size of the forest fragments by the average of the areas;

- LSI - landscape shape index. The SHAPE of each forest patch is calculated by the perimeter of the patch divided by the square root of the area and divided by four, with the most regular shape $=1$;

- ED - edge density, obtained by the sum of total forest edges divided by the total area.

We also quantified the land-use/land-cover composition of the riparian zone, considering the Brazilian Native Vegetation Protection Law $n^{\circ} 12,651$, sanctioned, with some vetoes, on May 25, 2012, and altered by Law $n^{0} 12,727$ from October 17, 2012, which defines its occupation by native vegetation, i.e., forest cover in this case.

This way, we adopted the Permanent Preservation Area (PPA) as a riparian zone, using a $30 \mathrm{~m}$ buffer along with the river network and a 50m buffer around springs as described in the previous study (Mello et al. 2018b).

\section{Water quality}

We evaluated the water quality variables as water temperature ( $\mathrm{T}$ ); $\mathrm{pH}$, dissolved oxygen (DO), total nitrogen (TN), total phosphorus (TP), total suspended solids (TSS), inorganic suspended solids (ISS), organic suspended solids (OSS), total coliforms (TC), fecal coliforms (FC), and turbidity. 
The water samples were collected at bi-weekly intervals during a hydrological year (October 2013 to October 2014), with a total of 24 observations for each site. We also measured the streamflow (Q).

The temperature $\left({ }^{\circ} \mathrm{C}\right), \mathrm{pH}$, and $\mathrm{DO}(\mathrm{mg} / \mathrm{L})$ were measured through an in-situ water quality detector $(\mathrm{YSI}$ 556 multiparameter system). Water samples were collected in duplicate using polyethylene bottles to determine Turbidity, TN, TP, TSS, ISS, and OSS, which were kept refrigerated and transported to the laboratory for advanced analysis, following standard methods (APHA 2005). Turbidity was obtained using an automatic turbidimeter (MS TEC - TB 1000).

The TN was determined by Kjeldahl digestion method (APHA 2005) using an automatic digester (Buchi K449). The spectrophotometric determination was used to measure TP (APHA 2005). The gravimetric analysis was used to obtain TSS, ISS, and OSS (APHA 2005), where $500 \mathrm{~mL}$ were filtrated for each sample. TSS is the total residue portion on the filter, ISS is the total solid portion that remains after the calcination, and OSS is the portion of the solids that is lost in the calcination process. TC and FC were detected by the multiple-tube technique with a $100 \mathrm{~mL}$ sample (CETESB 2018), and the results are given in Most Probable Number (MPN). We used a Lactose Broth for the presumptive identification of Coliforms, and the Brilliant Green Bile Broth for the confirmation and mensuration.

Streamflow (Q) was measured during all sampling times using a current-meter method by dividing the stream channel cross-section into various vertical subsections (Santos et al. 2001). In each subsection, the area was obtained by measuring the width and depth, and the water velocity was determined using a Current Meter (Global Water Flow Probe - 201). The total discharge was computed by summing the discharge of each subsection.

\section{Statistical analysis}

Relating the water quality, the variables were checked for normality and transformed, when necessary, using a logarithmic transformation. We calculated the mean and standard deviation of the water quality variables for watersheds. To evaluate if the watersheds with different forest cover patterns present different water quality, a multivariate analysis of variance (MANOVA) was applied with the use of the Hotelling-Lawley test in order to identify the differences between the watersheds regarding water quality variables. The Hotelling-Lawley Trace is the multivariate equivalent of the t-test, whether the two vectors of means for the two watersheds are sampled from the same sampling distribution (Carey 1998). We compared landscape metrics to identify which metrics could be responsible for this result.

The principal component analysis (PCA) was applied to check for differences in groups of variables between the watersheds and identify the water quality variables that influenced this result and their relation.

We also performed a Pearson's rank correlation to check for covariance between water quality variables. 
The statistical analyses were performed using the software RStudio (R Core Team 2014) and MVSP 3.22 (Kovach Computing Services 2007).

\section{Results}

\section{Watersheds physical characterization}

The W1 and W2 watersheds presented similar size ( 544.5 ha and 597.5, respectively), average slope (24.5\% and $26.6 \%$, respectively) and morphometric indexes ( $\mathrm{Kc}, \mathrm{lc}$ and $\mathrm{Kf})$. $\mathrm{W} 1$ presented values of $\mathrm{Kc}=$ $1.48, \mathrm{Ic}=0.45$ and $\mathrm{Kf}=0.31$. $\mathrm{W} 1$ presented values of $\mathrm{Kc}=1.50, \mathrm{lc}=0.44$ and $\mathrm{Kf}=0.37$. Both watersheds have oval shape considering $\mathrm{Kc}$ and an oblong shape according to Ic. Thus, they can be classified into oblong/oval shape according to Villela and Mattos (1975).

According to the slope classes proposed by EMBRAPA (1999), their reliefs are wavy to highly wavy (Fig $2 \mathrm{~B}$ ), considering that $51 \%$ of both watersheds belong to $20-45 \%$ slope class (highly wave relief) (Fig $2 \mathrm{~A}$ ) and about $32 \%$ of the W1 and $30 \%$ of the W2 presented slope values between $8 \%$ and $20 \%$ (wavy relief). The flat areas, with slope values lower than $3 \%$, occur in only about $1 \%$ of each watershed; slope between $3 \%$ and $8 \%$ (soft-wavy relief) represented about $7 \%$; and the mountainous relief ( $45 \%$ to $75 \%$ ) represented $8 \%$ and $11 \%$ of W1 and W2, respectively. Finally, the class of steeper relief ( $>75 \%$ slope) was the least representative class in the watershed with less than $0.5 \%$ in occupied area.

\section{Landscape composition and configuration}

The watersheds are mostly covered by native forest (Fig $2 A$ ) with $55 \%$ and $57 \%$ for W1 and W2 watersheds, respectively. Agriculture and pasture were the second and third most important landuse/land-cover types in the study area.

Agriculture comprises fast-growing vegetables (e.g., onion, potato, pumpkin, strawberry, and lettuce), representing $27 \%$ and $23 \%$, respectively, of W1 and W2 watersheds (Table 1 ). Pasture comprised grassland destined for livestock activity, even without cattle, covering $11.5 \%$ and $12.0 \%$ of the respective watersheds. Forestry, urban areas, wetlands, and water covered less than $4 \%$ of each watershed (Table 1).

Table 1 Land-use/land-cover composition (\%) of the low-order watersheds, regionally named as Gurgel (W1) and Vieirinhas (W2), in the Pirapora river basin, State of São Paulo, Brazil, and their respective riparian zones 


\begin{tabular}{c|c|c|c|c}
\hline & \multicolumn{2}{|c|}{ W1 } & \multicolumn{2}{c}{ W2 } \\
\hline land-use/land-cover & Watershed & Riparian Zone & Watershed & Riparian Zone \\
& & & & \\
\hline Water & 0.50 & 2.06 & 0.75 & 2.61 \\
Agriculture & 26.66 & 7.66 & 23.14 & 6.64 \\
Forestry & 3.28 & 2.66 & 1.92 & 0.06 \\
Forest & 55.16 & 70.39 & 57.40 & 76.85 \\
Pasture & 11.49 & 9.64 & 11.91 & 6.76 \\
Urban & 1.14 & 1.56 & 3.47 & 2.15 \\
Wetland & 1.77 & 6.04 & 1.40 & 4.93 \\
\hline
\end{tabular}

Considering the riparian zone composition, both watersheds presented a similar pattern, with the predominance of forest cover (70.39\% and $76.85 \%$ for W1 and W2 watersheds, respectively), followed by pasture and agriculture (Table 1).

We can observe that the watersheds have a similar number of patch (NP) and patch density (PD), however, their forest patches presented distinct spatial distribution and configuration. The W1 watershed has 18 forest patches and $3.28 \mathrm{NP} / 100$ ha and W2 has 19 forest patches and $3.18 \mathrm{NP} / 100$ ha (Table 2). W2 however showed smaller value for the largest patch index ( $\mathrm{LPI}=26.87 \%)$ and smaller value for coefficient of variation in patch area $(\mathrm{CV}=218.00 \%)$, and concomitantly higher values for mean shape index $(\mathrm{LSI}=1.75)$ and for edge density $(E D=91.02 \mathrm{~m} / \mathrm{ha})($ Table 1$)$.

Table 2 Landscape metrics for forest patches of the low-order watersheds, regionally named as Gurgel (W1) and Vieirinhas (W2), in the Pirapora river basin, State of São Paulo, Brazil

\begin{tabular}{l|c|c}
\hline \multirow{2}{*}{ Metrics } & \multicolumn{2}{|c}{ Watersheds } \\
\cline { 2 - 3 } NP & W1 & \multicolumn{1}{c}{ W2 } \\
\cline { 2 - 3 } PD (NP/100ha) & 18.00 & 19.00 \\
LPI (\%) & 3.28 & 3.18 \\
CV (\%) & 30.56 & 26.87 \\
LSI & 1.57 & 1.75 \\
ED (m/ha) & 69.25 & 91.02 \\
\hline
\end{tabular}

where NP: number of patches; PD: density of patches; LPI: largest patch index; CV: coefficient of variation of the patch size; LSI: mean patch shape index; e ED: edge density.

The LSI (1.75) value describes the predominance of irregular patches, that were associated with individual SHAPE values larger than 3 as also described by Forman (1995). For instance, the two largest patches in W2 had SHAPE > 3 while the largest patch in W1 presented SHAPE $=2.97$. In addition, W2 watershed presented higher values of ED than W1 (91 vs 69) representing the edge effect on the forest 
fragments. On the other hand, W1 has an only patch covering $40.6 \%$ (LPI - Table 1) of the landscape, that influenced the high value of $\mathrm{CV}$.

\section{Water quality}

The watersheds showed different water quality pattern, considering the variables evaluated. MANOVA analysis indicated that there is a significative difference (Hotelling-Lawley's $\lambda=2.86 ; F=6.55 ; P=0.001$ ) between the watersheds regarding water quality variables, especially related to TSS, ISS, OSS, turbidity, and TC with superior values of mean (M) and standard deviation (Sd) for W2. Conversely, other variables (T, pH, DO, TN, TP, and FC) had no significative difference, even with a general higher value for W2 watershed (Table 3).

Table 3 Water quality variables (WQ), their mean values (M) and standard deviation (PD), for the low-order watersheds, regionally named as Gurgel (W1) and Vieirinhas (W2), in the Pirapora river basin, State of São Paulo, Brazil

\begin{tabular}{|c|c|c|c|c|}
\hline \multirow[t]{2}{*}{ WQ } & \multicolumn{2}{|c|}{ W1 } & \multicolumn{2}{|c|}{ W2 } \\
\hline & M & PD & M & $\mathrm{PD}$ \\
\hline $\mathrm{T}\left(\mathrm{C}^{\circ}\right)$ & 13.52 & 2.76 & 13.81 & 2.44 \\
\hline pH & 5.78 & 0.93 & 6.40 & 0.92 \\
\hline DO (mg/L) & 7.75 & 0.73 & 8.04 & 0.74 \\
\hline Turbidity (NTU) & 13.95 & 3.59 & 17.90 & 9.28 \\
\hline TSS (mg/L) & 5.15 & 3.03 & 11.51 & 6.29 \\
\hline ISS (mg/L) & 2.80 & 2.35 & 7.22 & 4.97 \\
\hline OSS (mg/L) & 2.35 & 0.90 & 4.29 & 1.47 \\
\hline $\mathrm{TN}(\mathrm{mg} / \mathrm{L})$ & 0.22 & 0.15 & 0.21 & 0.15 \\
\hline $\mathrm{TP}(\mu \mathrm{g} / \mathrm{L})$ & 49.66 & 35.43 & 56.52 & 36.68 \\
\hline TC (NMP) & 298 & 415 & 540 & 544 \\
\hline FC (NMP) & 106 & 134 & 102 & 134 \\
\hline
\end{tabular}

where $\mathrm{T}=$ temperature; $\mathrm{DO}=$ dissolved oxygen; $\mathrm{TSS}=$ total suspended solids; ISS=inorganic suspended solids; OSS=organic suspended solids; $\mathrm{TN}=$ total nitrogen; $\mathrm{TP}=$ total phosphorus; $\mathrm{TC}=$ total coliforms; $\mathrm{FC}=\mathrm{fecal}$ coliforms.

Observing the individual variables values (Table 3 ), we noticed $\mathrm{pH}$ near 6 , that is considered slightly acidic and DO values were higher than $6 \mathrm{mg} \cdot \mathrm{L}^{-1}$.

In general, turbidity values were below 20 NTU, having W2 a turbidity of 17.9 NTU (PD = 9.28) and W1 a value of $13.95 \mathrm{NTU}(\mathrm{PD}=3.59)$, but we can observe that the variation of turbidity values during the year 
was higher in W2 than W1 (PD - Table 3). The higher value for W2 was 56.7, while for W1 all values remained below 20. The same tendency was found for TSS, ISS and OSS, with higher values of M and PD for W2.

Concerning nutrients, we can observe that the watersheds obtained similar values for TN with $\mathrm{M}$ values of $0.2 \mathrm{mg} / \mathrm{L}(P D=0.15 \mathrm{mg} / \mathrm{L})$ and, TP with higher value for W2 $(56.5 \mu \mathrm{g} / \mathrm{L})$ than W1 $(49,7 \mu \mathrm{g} / \mathrm{L})$, however it did not present statistical different. Nevertheless, TP varied during the year, and we had three samples (at the two watersheds) with values superior of $0.01 \mathrm{mg} / \mathrm{L}$, increasing PD value. TC had the same pattern with superior values in W2 despite its FC, that was a little bit low, compared with W1 mean (Table $3)$.

The principal component Analysis (PCA) indicated a data grouping by watersheds with the first axis explaining $36.0 \%$ of the data variability and the second axis $27.4 \%$, that means a total of $63.4 \%$ of explanation (Fig 3).

The first axis comprises Q, ISS, OSS, TSS and turbidity, indicating relationships among them and, showing that the highest NTU and TSS values occurred at W2. Since the increase in Q corresponds to an increase in the TSS in the water, so the $Q$ variation in function of the precipitation should have an influence on the inflow of solids into the river.

We can observe that there is a higher solids runoff with streamflow increasing in W2 than in W1 as well as for TC and FC (axis 2 - Fig 3).

There is a correlation between suspended solids and turbidity, especially for ISS ( $r=0.82)$ and TSS $(r=$ $0.78)$, which presented a high correlation between then $(r=0.99)$. OSS presented a correlation of 0.86 with TSS. Other variables that presented correlation with TSS and ISS were $P(r=0.52$ and 0.53 respectively) and TC $(r=0.53)$. Both TSS and ISS presented a correlation with $Q(r=0.67$ and 0.62 , respectively). Another relation found with Person's correlation was DO and TN with temperature, but in this case, a negative correlation ( $r=-0.45$ and -0.48 , respectively).

\section{Discussion}

The headwaters of Pirapora river basin presented similar morphometry and slope, which allows the analysis of the effect of land-use/land-cover pattern on water quality of this watersheds. Although they are covered mostly by forest, the agricultural activities may be responsible for inputs of solids and nutrients into the streams, especially phosphorus. The watersheds have similar land-use/land-cover composition and riparian zone characteristics but differ in landscape configuration, and they presented differences regarding the water quality variables, which indicates that land-use/land-cover configuration is important to water quality response in low-order streams.

Both watersheds presented an oblong/oval shape, which indicates low to medium tendency of floods according to Villela and Matos (1975). According to Villela and Mattos (1975), elongated basins do not 
favor the concentration of the fluvial flow, that is, the water flows reach the outlet of the watershed at different times from the beginning of the rain event. Thus, there is a low tendency to flooding and, consequently, less permanence of pollutants. On the other hand, the watersheds have wavy to highly wavy relief, indicating that they have very steep areas, the same found by (Pissarra et al. (2010) for headwater streams in Brazil. The authors emphasize that head watersheds are characterized by steep relief and dendritic drainage network, which makes erosion more rapid in headwater watersheds than in larger, higher-order but lower slope watersheds (Campos Pinto et al. 2016; Sosa Gonzalez et al. 2016). The slope is one of the main factors related to the erosive processes specially in tropical areas (Sosa Gonzalez et al. 2016), influencing agricultural management practices (Vijith et al. 2018), which is the case of short-cycle crops in our study area.

Although they are covered mostly by native forest, both watersheds presented agriculture as the second most important land-use/land-cover class. This generates a concern about the adequate management of this land use for the maintenance of water quality of the Pirapora river. The streams, however, presented in general good water quality, been classified into the class I, according to CONAMA Framework Resolution 357/05 that fixed the conditions for establishing water quality categories in Brazilian aquatic ecosystems. Similar results were found by Pinto et al. (2013) and Fernandes et al. (2015) in small watersheds in the Atlantic Forest. Both watersheds in our study presented more than $70 \%$ of the riparian zone covered by native forest, which is a high percentage of compliance of the environmental law and can be related to the good water quality in the agricultural watersheds (Mello et al. 2017). These results highlight the importance of forest cover for the maintenance of water quality in agricultural small watersheds.

Nevertheless, agricultural activities may have been responsible for TP runoff into the river, in concentrations higher than those established for class I rivers $(0.01 \mathrm{mg} / \mathrm{L})$, in some samples during the period evaluated. The water drained from agricultural lands leads to the runoff of components present on the soil surface, such as phosphorus (Gonzales-Inca et al. 2015). The contribution of phosphorus in the rivers is one of the major causes of waterbodies eutrophication, being limiting for the aquatic community. In the other hand, the results indicate that DO is not a limiting factor for most aquatic vertebrates and invertebrates, which usually does not support concentrations below $3 \mathrm{mg} / \mathrm{L}$. According to Welch and Lindell (2004), there is a limit of $5 \mathrm{mg} / \mathrm{L}$ for warm water (tropic rivers) to sustain fish populations.

Besides the importance of land-use/land-cover composition, our results show that forest cover configuration also influenced water quality, and forest fragmentation has a negative impact on water quality. The watershed W2, which has more elongated fragments, larger edge area and less aggregate forest cover, presented higher values of suspended solids, turbidity, and TC than W1. The same occurs for water quality variability during the year, that is higher for W2 than W1, which is also an indicative of anthropogenic disturbance on water resources (Mello et al. 2018a). Ding et al. (2016) and Ou et al. (2016) observed that landscapes with aggregated forest areas tend to have greater ability to absorb and attach pollutants than landscapes with scattered forest areas. The watershed W1 presented forest configuration 
more aggreged than the W2, with LPI of $40.56 \%$, while W2 presented higher values of LSI and ED (Table 2).

Other studies also found a negative relationship between LSI and ED with water quality (Uuemaa et al. 2005). These metrics are related to the complexity of forest patches shape and to the edge effect: the larger the value, the more elongated (or irregular) and complex the patch shape.

Otherwise, Huang et al. (2016) did not detect a significant correlation between these metrics due to the spatial resolution $(30 \mathrm{~m})$ used in the mapping, and the authors suggested that for low-order streams, refined scale data such as the present study $(5 \mathrm{~m})$ are necessary for better understanding effects of landscape configuration in small watersheds. Different from our results, Clément et al. (2017) found a positive relation between the shape complexity of patches and water quality in Canada using only periphytic algae as water quality indicator, showing that results can differ according to the region, spatial scale of study and the variables selected as indicators.

Regarding the water quality variables, solids and turbidity are correlated, specially TSS and ISS, since both represent particles present in the water. According to Mansor et al. (2006), diffuse pollution in rural areas is largely due to surface runoff from agricultural lands, which carries sediments and nutrients into to the stream channel, and this process is accentuated in rainy periods (Gonzales-Inca et al. 2015). TP and TC were correlated to suspended solids, showing that both variables are dependent on sediment (Huang et al. 2016), and because TP is easily adsorbed on mineral particles (Silva et al. 2009). In the present study, solids in water are associated with streamflow variations, showing that sediment input in streams is influenced by increased runoff, which is expected for tropical rivers (Uriarte et al. 2011). This relationship was more pronounced in the watershed $W 2$, showing that forest fragmentation negatively impacts the potential retention of these particles.

Therefore, landscape configuration is an important aspect to be considered in the management of headwater watersheds since it affects stream water quality (Zhang et al. 2018). The conservation and configuration of forest areas in watersheds of low-order streams is extremely important to ensure the maintenance of water quality for public supply, and agricultural management should be done in a way that minimizes the contribution of sediment and nutrients into the waterbodies, considering the seasonal hydrological variations and the generally steep relief of these regions.

Thus, land-use planning and best agricultural practices are essential to protect and improve river basins' water quality. The degradation of water quality affects not only the environment but also human health (Hutton 2012). The improvements in the environmental quality of the waters impact the health and well-being of the population (WHO 2017).

\section{Conclusion}

Forest pattern, considering its area and configuration, contributes to the maintenance of water quality, and forest fragmentation has a negative impact on water quality in low-order streams, especially during 
rainy periods, increasing mainly particles in the water. Besides the forest cover, agricultural activities may be responsible for inputs of solids and nutrients into the streams, especially phosphorus, considering that these areas have steep relief. Thus, it is necessary to consider the landscape configuration for the management of low-order streams in agricultural landscapes. Future extensions of this study can evaluate the effects of forest configuration in watersheds of different size, relief, and land-use/land-cover composition.

\section{Bibliography}

Álvarez-Cabria M, Barquín J, Peñas FJ (2016) Modelling the spatial and seasonal variability of water quality for entire river networks: Relationships with natural and anthropogenic factors. Sci Total Environ 545-546:152-162. https://doi.org/10.1016/j.scitotenv.2015.12.109

Amuchástegui G, di Franco L, Feijoó C (2016) Catchment morphometric characteristics, land use and water chemistry in Pampean streams: a regional approach. Hydrobiologia 767:65-79. https://doi.org/10.1007/s10750-015-2478-8

APHA (ed) (2005) Standard Methods for the Examination of Water \& Wastewater, Centennial Edition, 21st edn. APHA (American Public Health Association), Washington

Bailão EFLC, Santos LAC, Almeida SDS, et al (2020) Effect of land-use pattern on the physicochemical and genotoxic properties of water in a low-order stream in Central Brazil. Rev ambiente água 15:1. https://doi.org/10.4136/ambi-agua.2486

Bakure BZ, Fikadu S, Malu A (2020) Analysis of physicochemical water quality parameters for streams under agricultural, urban and forest land-use types: in the case of gilgel Gibe catchment, Southwest Ethiopia. Appl Water Sci 10:234. https://doi.org/10.1007/s13201-020-01318-9

Brown AE, Zhang L, McMahon TA, et al (2005) A review of paired catchment studies for determining changes in water yield resulting from alterations in vegetation. $J$ Hydrol (Amst) 310:28-61. https://doi.org/10.1016/j.jhydrol.2004.12.010

Bu H, Meng W, Zhang Y, Wan J (2014) Relationships between land use patterns and water quality in the Taizi River basin, China. Ecological Indicators 41:187-197.

https://doi.org/10.1016/j.ecolind.2014.02.003

Campos Pinto L, de Mello CR, Norton LD, et al (2016) Spatial prediction of soil-water transmissivity based on fuzzy logic in a Brazilian headwater watershed. CATENA 143:26-34.

https://doi.org/10.1016/j.catena.2016.03.033

Cardoso CA, Dias HCT, Soares CPB, Martins SV (2006) Morphometric characterization of Debossan river watershed, Nova Firburgo, RJ. Rev Árvore 30:241-248. https://doi.org/10.1590/S0100-

67622006000200011

Page 15/22 
Carey G (1998) Multivariate Analysis of Variance (MANOVA): I. Theory. Colorado

Carneiro CDR, Bistrichi CA, Ponçano WL, Alameida MA (1981) Mapa Geomorfológico do Estado de São Paulo (Geomorphological Map of the State of São Paulo). Instituto de Pesquisas Tecnológicas, São Paulo

Castillo MM, Morales H, Valencia E, et al (2012) The effects of human land use on flow regime and water chemistry of headwater streams in the highlands of Chiapas. Knowl Managt Aquatic Ecosyst 09. https://doi.org/10.1051/kmae/2013035

CEPAGRI (2020) Centro de Pesquisas Meteorológicas e Climáticas Aplicadas à Agricultura CEPAGRI/UNICAMP. https://www.cpa.unicamp.br/. Accessed 5 Jan 2019

CETESB (2018) Total coliforms, thermotolerant coliforms and Escherichia coli - Procedure for multipletube technique. Companhia Ambiental do Estado de São Paulo - CETESB, São Paulo

Clément F, Ruiz J, Rodríguez MA, et al (2017) Landscape diversity and forest edge density regulate stream water quality in agricultural catchments. Ecological Indicators 72:627-639.

https://doi.org/10.1016/j.ecolind.2016.09.001

Ding J, Jiang Y, Liu Q, et al (2016) Influences of the land use pattern on water quality in low-order streams of the Dongjiang River basin, China: A multi-scale analysis. Sci Total Environ 551-552:205-216. https://doi.org/10.1016/j.scitotenv.2016.01.162

EMBRAPA (1999) Classificação de Solos do Estado de São Paulo (Classification of Soils of the State of São Paulo). Empresa Brasileira de Pesquisa Agropecuária (EMBRAPA), Rio de Janeiro

Fernandes MM, Ceddia MB, Francelino MR, Fernandes MR de M (2015) Environmental diagnosis of the riparian zone and quality of water in two micro watersheds used for human supply. IRRIGA

Freeman MC, Pringle CM, Jackson CR (2007) Hydrologic Connectivity and the Contribution of Stream Headwaters to Ecological Integrity at Regional Scales1. JAWRA Journal of the American Water Resources Association 43:5-14. https://doi.org/10.1111/j.1752-1688.2007.00002.x

Goldstein JH, Caldarone G, Duarte TK, et al (2012) Integrating ecosystem-service tradeoffs into land-use decisions. Proc Natl Acad Sci USA 109:7565-7570. https://doi.org/10.1073/pnas.1201040109

Gomi T, Sidle RC, Richardson JS (2002) Understanding Processes and Downstream Linkages of Headwater Systems. Bioscience 52:905. https://doi.org/10.1641/00063568(2002)052[0905:UPADLO]2.0.CO;2

Gonzales-Inca CA, Kalliola R, Kirkkala T, Lepistö A (2015) Multiscale landscape pattern affecting on stream water quality in agricultural watershed, SW finland. Water Resour Manage 29:1669-1682. https://doi.org/10.1007/s11269-014-0903-9 
Huang Z, Han L, Zeng L, et al (2016) Effects of land use patterns on stream water quality: a case study of a small-scale watershed in the Three Gorges Reservoir Area, China. Environ Sci Pollut Res Int 23:39433955. https://doi.org/10.1007/s11356-015-5874-8

Hutton G (2012) Global costs and benefits of drinking-water supply and sanitation interventions to reach the MDG target and universal coverage. World Health Organization - WHO, Geneva, Switzerland

IBGE (2020) Instituto Brasileiro de Geografia e Estatística (IBGE). In: Instituto Brasileiro de Geografia e Estatística (IBGE). https://www.ibge.gov.br/. Accessed 17 Feb 2021

IBGE (ed) (2013) Manual técnico de uso da terra: Divulga os procedimentos metodológicos utilizados nos estudos e pesquisas de geociências, 3rd edn. Instituto Brasileiro de Geografia e Estatística - IBGE, Rio de Janeiro/Brasil

Kovach Computing Services (2007) Multi-Variate Statistical Package - MVSP Plus . Version 3.1. Kovach Computing Services

Mansor MTC, Teixeira Filho J, Roston DM (2006) Preliminary assessment of diffused loads from rural areas in a sub-basin of the Jaguari River, SP, Brazil. Rev bras eng agríc ambient 10:715-723. https://doi.org/10.1590/S1415-43662006000300026

McGarigal K (2015) FRAGSTATS help. Documentation for FRAGSTATS 4:

Mello K de, Randhir TO, Valente RA, Vettorazzi CA (2017) Riparian restoration for protecting water quality in tropical agricultural watersheds. Ecol Eng 108:514-524.

https://doi.org/10.1016/j.ecoleng.2017.06.049

Mello K de, Taniwaki RH, Paula FR de, et al (2020) Multiscale land use impacts on water quality: Assessment, planning, and future perspectives in Brazil. J Environ Manage 270:110879. https://doi.org/10.1016/j.jenvman.2020.110879

Mello K de, Valente RA, Randhir TO, Vettorazzi CA (2018a) Impacts of tropical forest cover on water quality in agricultural watersheds in southeastern Brazil. Ecological Indicators 93:1293-1301. https://doi.org/10.1016/j.ecolind.2018.06.030

Mello K de, Valente RA, Randhir TO, et al (2018b) Effects of land use and land cover on water quality of low-order streams in Southeastern Brazil: Watershed versus riparian zone. CATENA 167:130-138. https://doi.org/10.1016/j.catena.2018.04.027

Mello K, Randhir T (2018) Diagnosis of water crises in the metropolitan area of São Paulo: policy opportunities for sustainability. Urban Water Journal 15:53-60.

https://doi.org/10.1080/1573062X.2017.1395895 
Ou Y, Wang X, Wang L, Rousseau AN (2016) Landscape influences on water quality in riparian buffer zone of drinking water source area, Northern China. Environ Earth Sci 75:114.

https://doi.org/10.1007/s12665-015-4884-7

Pinto LC, Mello CR de, Ávila LF (2013) Water quality indicators in the Mantiqueira Range region, Minas Gerais state. CERNE 19:687-692. https://doi.org/10.1590/S0104-77602013000400020

Pissarra TCT, Rodrigues FM, Politano W, Galbiatti JA (2010) Morfometria de microbacias do Córrego Rico, afluente do Rio Mogi-Guaçu, Estado de São Paulo, Brasil. Rev Árvore 34:669-676.

https://doi.org/10.1590/S0100-67622010000400011

Rossi M (2017) Mapa pedológico do Estado de São Paulo: revisado e ampliado. São Paulo: Instituto Florestal 1:

R Core Team (2014) R: A Language and Environment for Statistical Computing. Version 4. R Foundation for Statistical Computing, Vienna, Austria. URL https://www.R-project.org

Santos ID, Fill H, Sugai MR, et al (2001) Applied Hydrometry. Lactec, Curitiba

Schilling KE, Jacobson P (2014) Effectiveness of natural riparian buffers to reduce subsurface nutrient losses to incised streams. CATENA 114:140-148. https://doi.org/10.1016/j.catena.2013.11.005

Shehab ZN, Jamil NR, Aris AZ, Shafie NS (2021) Spatial variation impact of landscape patterns and land use on water quality across an urbanized watershed in Bentong, Malaysia. Ecological Indicators 122:107254. https://doi.org/10.1016/j.ecolind.2020.107254

Shi P, Zhang Y, Li Z, et al (2017) Influence of land use and land cover patterns on seasonal water quality at multi-spatial scales. CATENA 151:182-190. https://doi.org/10.1016/j.catena.2016.12.017

Silva GS da, Silva GS da, Sousa ER de, et al (2009) Phosphorus and nitrogen in waters of the ocoí river sub-basin, Itaipu reservoir tributary. J Braz Chem Soc 20:1580-1588. https://doi.org/10.1590/S010350532009000900004

Silva VAM, Mello K de, Vettorazzi CA, et al (2017) Priority areas for forest conservation, aiming at the maintenance of water resources, through the multicriteria evaluation1. Rev Árvore 41:.

https://doi.org/10.1590/1806-90882017000100019

Song Y, Song X, Shao G, Hu T (2020) Effects of land use on stream water quality in the rapidly urbanized areas: A multiscale analysis. Water (Basel) 12:1123. https://doi.org/10.3390/w12041123

Sosa Gonzalez V, Bierman PR, Fernandes NF, Rood DH (2016) Long-term background denudation rates of southern and southeastern Brazilian watersheds estimated with cosmogenic $10 \mathrm{Be}$. Geomorphology 268:54-63. https://doi.org/10.1016/j.geomorph.2016.05.024 
Tanaka MO, Souza ALT de, Moschini LE, Oliveira AK de (2016) Influence of watershed land use and riparian characteristics on biological indicators of stream water quality in southeastern Brazil. Agriculture, Ecosystems \& Environment 216:333-339. https://doi.org/10.1016/j.agee.2015.10.016

Taniwaki RH, Cassiano CC, Fransozi AA, et al (2019) Effects of land-use changes on structural characteristics of tropical high-altitude Andean headwater streams. Limnologica 74:1-7. https://doi.org/10.1016/j.limno.2018.10.002

Taniwaki RH, Piggott JJ, Ferraz SFB, Matthaei CD (2017) Climate change and multiple stressors in small tropical streams. Hydrobiologia 793:41-53. https://doi.org/10.1007/s10750-016-2907-3

Uriarte M, Yackulic CB, Lim Y, Arce-Nazario JA (2011) Influence of land use on water quality in a tropical landscape: a multi-scale analysis. Landsc Ecol 26:1151-1164. https://doi.org/10.1007/s10980-0119642-y

Uuemaa E, Roosaare J, Mander Ü (2005) Scale dependence of landscape metrics and their indicatory value for nutrient and organic matter losses from catchments. Ecological Indicators 5:350-369. https://doi.org/10.1016/j.ecolind.2005.03.009

Vannote RL, Minshall GW, Cummins KW, et al (1980) The River Continuum Concept. Can J Fish Aquat Sci 37:130-137. https://doi.org/10.1139/f80-017

Vettorazzi CA, Valente RA (2016) Priority areas for forest restoration aiming at the conservation of water resources. Ecol Eng 94:255-267. https://doi.org/10.1016/j.ecoleng.2016.05.069

Vijith H, Hurmain A, Dodge-Wan D (2018) Impacts of land use changes and land cover alteration on soil erosion rates and vulnerability of tropical mountain ranges in Borneo. Remote Sensing Applications: Society and Environment 12:57-69. https://doi.org/10.1016/j.rsase.2018.09.003

Villela SM, Mattos A (eds) (1975) Hidrologia Aplicada São Paulo. McGraw-Hill do Brasil, São Paulo

Welch EB, Lindell T (2004) Ecological Effects of Waste Water: Applied limnology and pollutant effects, 3rd edn. Taylor \& Francis e-Library, London

WHO (ed) (2017) Guidelines for drinking-water quality: fourth edition incorporating the first addendum. World Health Organization, Geneva

Wu J, Jin Y, Hao Y, Lu J (2021) Identification of the control factors affecting water quality variation at multi-spatial scales in a headwater watershed. Environ Sci Pollut Res Int 28:11129-11141. https://doi.org/10.1007/s11356-020-11352-4

Xie Y, Yu X, Ng NC, et al (2018) Exploring the dynamic correlation of landscape composition and habitat fragmentation with surface water quality in the Shenzhen river and deep bay cross-border watershed, China. Ecological Indicators 90:231-246. https://doi.org/10.1016/j.ecolind.2017.11.051 
Zhang W, Chen D, Li H (2018) Spatio-temporal dynamics of water quality and their linkages with the watershed landscape in highly disturbed headwater watersheds in China. Environ Sci Pollut Res Int 25:35287-35300. https://doi.org/10.1007/s11356-018-3310-6

\section{Figures}

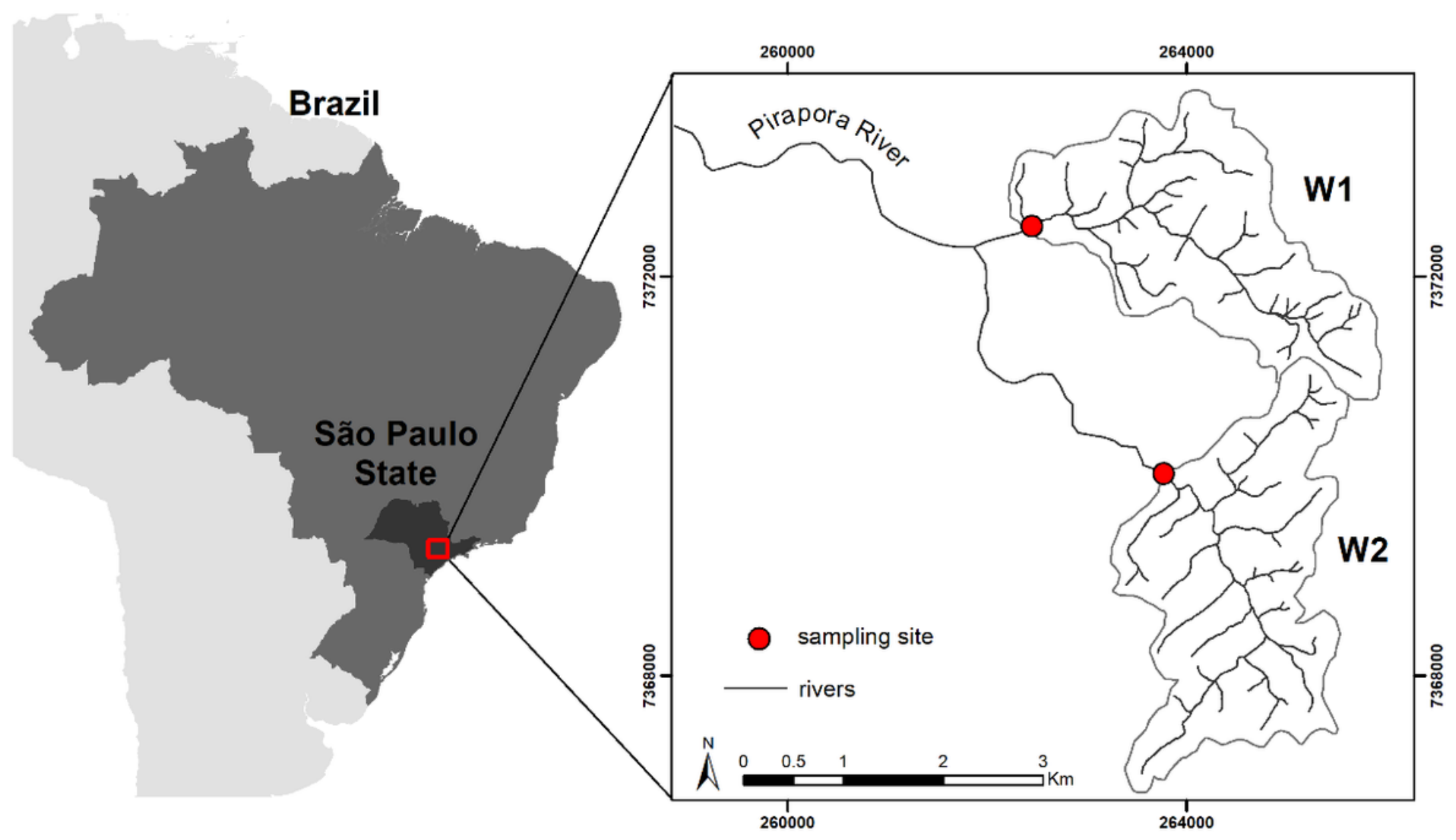

Figure 1

Location of main tributaries of the Pirapora river, regionally named as Gurgel (W1) and Vieirinhas (W2), São Paulo State, Brazil. 

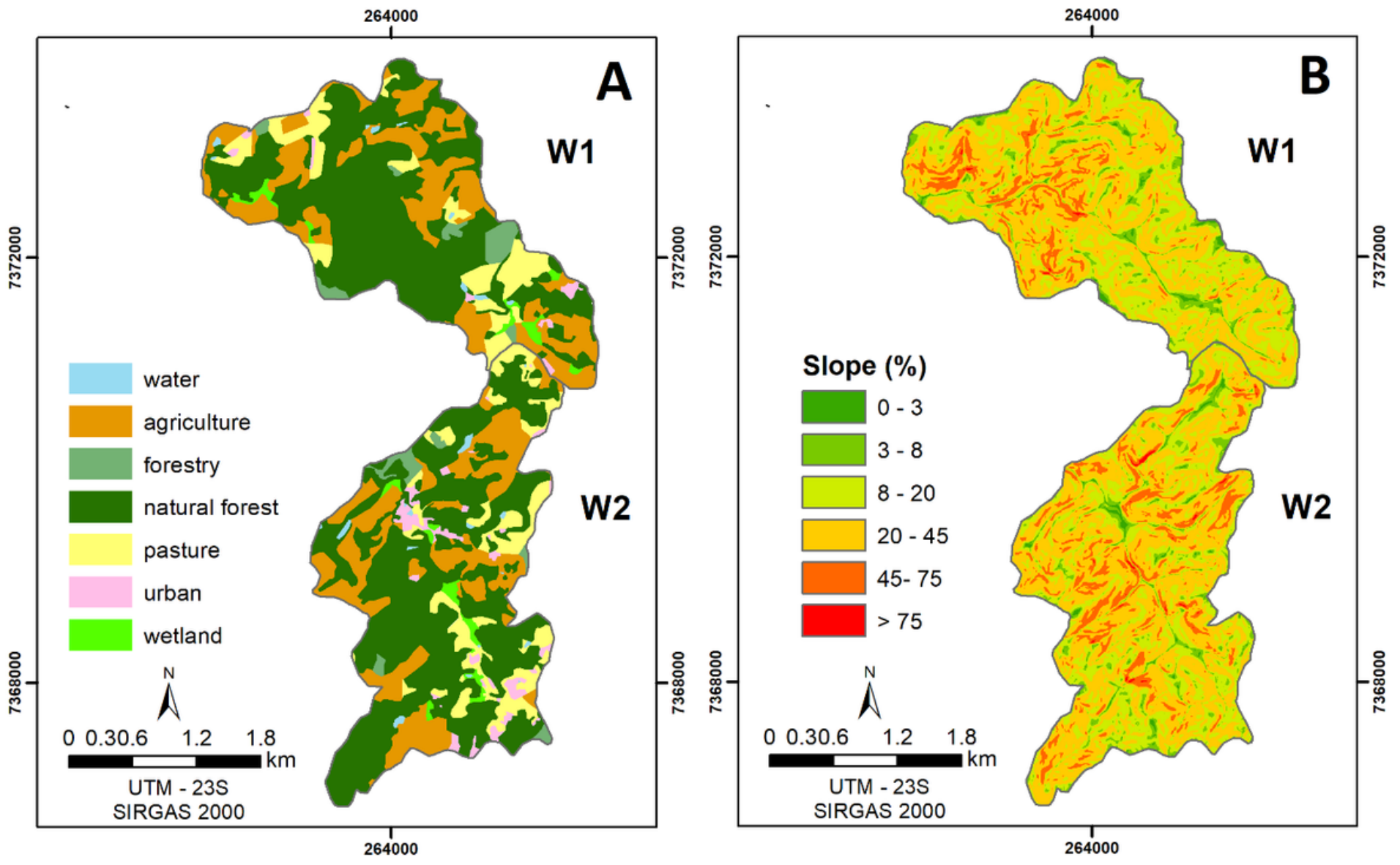

Figure 2

Land-use/land-cover composition (A) and slope (B) of the low-order watersheds, regionally named as Gurgel (W1) and Vieirinhas (W2), in the Pirapora river basin, State of São Paulo, Brazil 


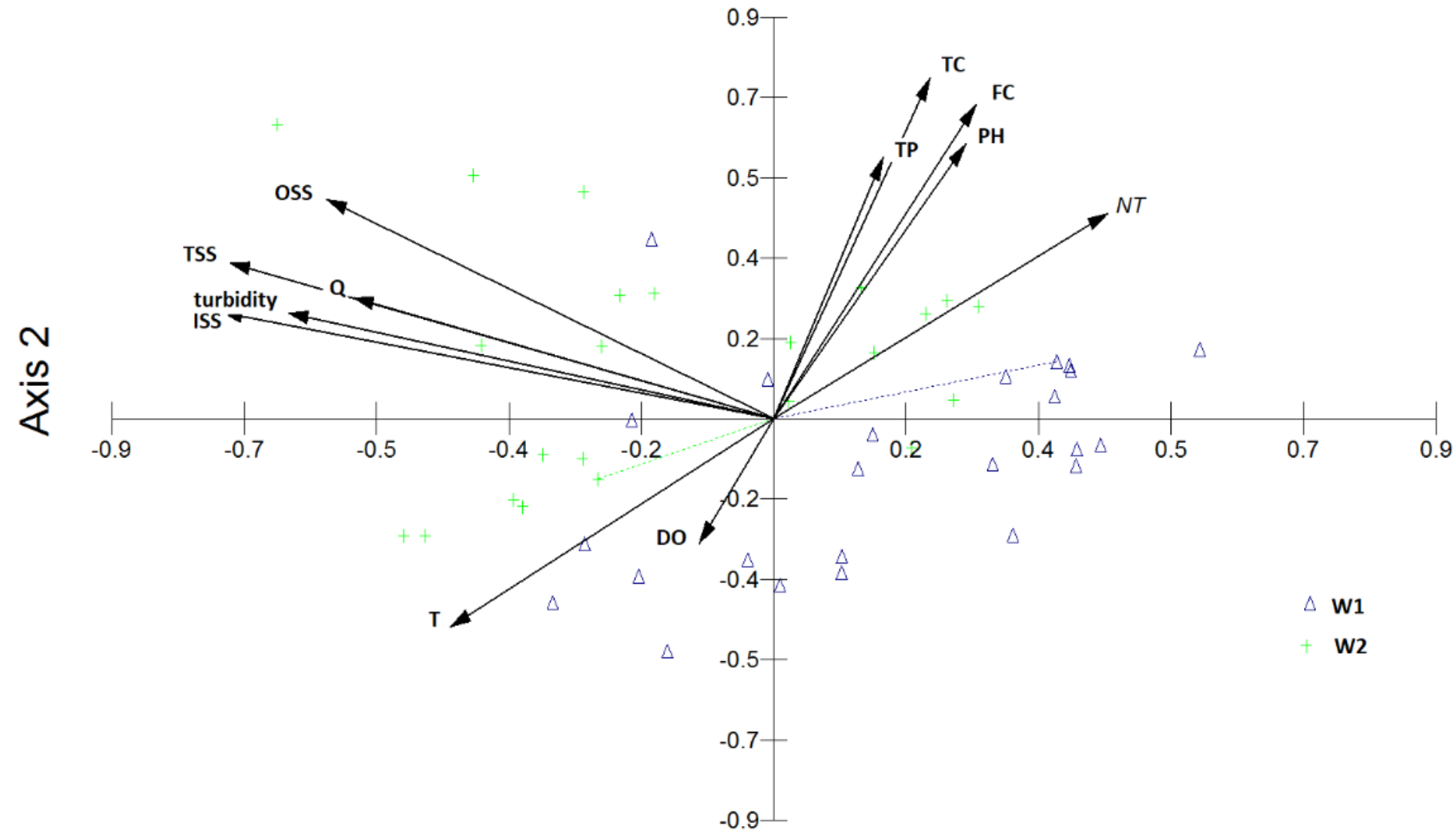

\section{Axis 1}

\section{Figure 3}

Principal Component Analysis (PCA) of water quality variables for the low-order watersheds, regionally named as Gurgel (W1) and Vieirinhas (W2), in the Pirapora river basin, State of São Paulo, Brazil 